\title{
Uptake of hypobromous acid (HOBr) by aqueous sulfuric acid solutions: low-temperature solubility and reaction
}

\author{
L. T. Iraci ${ }^{1}$, R. R. Michelsen ${ }^{1,2}$, S. F. M. Ashbourn ${ }^{1,3}$, T. A. Rammer ${ }^{4}$, and D. M. Golden \\ ${ }^{1}$ Atmospheric Chemistry \& Dynamics Branch, NASA Ames Res. Center, Mail Stop 245-5, Moffett Field, CA 94035, USA \\ ${ }^{2}$ National Research Council Associate, USA \\ ${ }^{3}$ now at: Earth Tech, Ltd., 91 Brick Lane, London EI 6QL, UK \\ ${ }^{4}$ SRI International NSF Research Experiences for Undergraduates Program, Menlo Park, CA 94025, USA \\ ${ }^{5}$ Department of Mechanical Engineering, Stanford University, Stanford, CA 94305, USA
}

Received: 14 February 2005 - Published in Atmos. Chem. Phys. Discuss.: 9 March 2005

Revised: 20 May 2005 - Accepted: 20 May 2005 - Published: 21 June 2005

\begin{abstract}
Hypobromous acid (HOBr) is a key species linking inorganic bromine to the chlorine and odd hydrogen chemical families. We have measured the solubility of $\mathrm{HOBr}$ in $45-70 \mathrm{wt} \%$ sulfuric acid solutions representative of upper tropospheric and lower stratospheric aerosol composition. Over the temperature range $201-252 \mathrm{~K}, \mathrm{HOBr}$ is quite soluble in sulfuric acid, with an effective Henry's law coefficient, $H^{*}=10^{4}-10^{7} \mathrm{~mol} \mathrm{~L}^{-1} \mathrm{~atm}^{-1} . H^{*}$ is inversely dependent on temperature, with $\Delta H=-45.0 \pm 5.4 \mathrm{~kJ} \mathrm{~mol}^{-1}$ and $\Delta S=-101 \pm 24 \mathrm{~J} \mathrm{~mol}^{-1} \mathrm{~K}^{-1}$ for $55-70 \mathrm{wt} \% \mathrm{H}_{2} \mathrm{SO}_{4}$ solutions. Our study includes temperatures which overlap both previous measurements of $\mathrm{HOBr}$ solubility. For uptake into $55-70 \mathrm{wt} \% \mathrm{H}_{2} \mathrm{SO}_{4}$, the solubility is described by $\log$ $H^{*}=(2349 \pm 280) / \mathrm{T}-(5.27 \pm 1.24)$. At temperatures colder than $\sim 213 \mathrm{~K}$, the solubility of $\mathrm{HOBr}$ in $45 \mathrm{wt} \% \mathrm{H}_{2} \mathrm{SO}_{4}$ is at least a factor of five larger than in $70 \mathrm{wt} \% \mathrm{H}_{2} \mathrm{SO}_{4}$, with $\log H^{*}=(3665 \pm 270) / T-(10.63 \pm 1.23)$. The solubility of $\mathrm{HOBr}$ is comparable to that of $\mathrm{HBr}$, indicating that upper tropospheric and lower stratospheric aerosols should contain equilibrium concentrations of $\mathrm{HOBr}$ which equal or exceed those of $\mathrm{HBr}$. Upon uptake of $\mathrm{HOBr}$ into aqueous sulfuric acid in the presence of other brominated gases, particularly for $70 \mathrm{wt} \% \mathrm{H}_{2} \mathrm{SO}_{4}$ solution, our measurements demonstrate chemical reaction of $\mathrm{HOBr}$ followed by evolution of gaseous products including $\mathrm{Br}_{2} \mathrm{O}$ and $\mathrm{Br}_{2}$.
\end{abstract}

\footnotetext{
Correspondence to: L. T. Iraci

(Laura.T.Iraci@nasa.gov)
}

\section{Introduction}

Halogen species are known to catalytically destroy ozone in many regions of the atmosphere. Bromine is the dominant halogen responsible for the near-total loss of ozone at ground level in high-latitude springtime events (Martinez et al., 1999), and it participates in approximately $50 \%$ of the stratospheric ozone depletion observed over the polar regions in the springtime (Chipperfield and Pyle, 1998; WMO, 2003). In addition to direct catalytic losses, bromine compounds can indirectly enhance ozone loss through coupling to other radical families.

In the Arctic boundary layer, hypobromous acid (HOBr) is believed to play a significant role in Br activation during rapid ozone depletion events (Fan and Jacob, 1992; Finlayson-Pitts and Pitts, 2000). Observations of Foster et al. (2001), who found higher levels of $\mathrm{Br}_{2}$ in the snowpack interstitial air than in the air above the surface, strongly support the occurrence of

$\mathrm{HOBr}+\mathrm{HBr} \longrightarrow \mathrm{Br}_{2}+\mathrm{H}_{2} \mathrm{O}$

on snowpack surfaces in the Arctic. Reaction 1 has been studied at room temperature; Beckwith et al. (1996) found the forward reaction to be general acid catalyzed, involving $\mathrm{Br}^{+}$transfer to $\mathrm{Br}^{-}$as proton transfer occurs from the catalyst to HOBr. Wintertime Arctic haze events, which are dominated by acidic sulfate particles (Barrie and Barrie, 1990), are clearly a suitable environment for such aqueous phase conversion. In addition, autocatalytic reactions involving $\mathrm{HOBr}$ are the most likely source of elevated $\mathrm{BrO}$ observed over the Dead Sea (Matveev et al., 2001). 
Higher in the atmosphere, Murphy and Thompson (2000) observed that bromine was most commonly found in aerosols just above the tropopause, where particulate $\mathrm{Br}$ may represent a significant fraction of total inorganic Br. Strong evidence indicates that $\mathrm{HOBr}$ is the major stratospheric bromine reservoir before sunrise at all latitudes (Lary et al., 1996; Sinnhuber et al., 2002). Photolysis of $\mathrm{HOBr}$ yields $\mathrm{OH}$ radicals, providing an important coupling between the bromine and odd-hydrogen families. $\mathrm{HOBr}$ is generated in/on aerosol particles via the hydrolysis of $\mathrm{BrONO}_{2}$, indicating that the aqueous-phase behavior of $\mathrm{HOBr}$ may be important, particularly at night. Furthermore, the coupling reaction

$\mathrm{HOBr}+\mathrm{HCl} \longrightarrow \mathrm{BrCl}+\mathrm{H}_{2} \mathrm{O}$

may provide a pathway for chlorine activation on sulfate aerosols at temperatures warmer than those required for PSC formation (Michelsen et al., 1999; Danilin and McConnell, 1995; Lary et al., 1996), potentially leading to chlorine activation earlier in the season or over an expanded geographical area. This pathway could be especially important under conditions where chlorine processing is incomplete, such as at the polar vortex edge, or in warmer arctic winters. Perhaps most importantly, as the stratosphere cools due to climate change processes, larger areas may have sufficiently cold temperatures for stratospheric chlorine activation via coupling with bromine on sulfate aerosols.

Clearly it is important to understand the multiphase behavior of $\mathrm{HOBr}$ under atmospherically relevant conditions. Here we present measurements of $\mathrm{HOBr}$ solubility in lowtemperature aqueous sulfuric acid $\left(\mathrm{H}_{2} \mathrm{SO}_{4}\right)$ solutions representative of stratospheric sulfate aerosol particles. We also provide evidence for $\mathrm{Br}_{2}$ and $\mathrm{Br}_{2} \mathrm{O}$ production when $\mathrm{HOBr}$ and $\mathrm{HBr}$ interact in cold, acidic solution. $\mathrm{Br}_{2}$ may be produced by Reaction 1, and $\mathrm{Br}_{2} \mathrm{O}$ is expected in the presence of a strong dehydrating agent such as $\mathrm{H}_{2} \mathrm{SO}_{4}$ :

$\mathrm{HOBr}+\mathrm{HOBr} \longrightarrow \mathrm{Br}_{2} \mathrm{O}+\mathrm{H}_{2} \mathrm{O}$.

\section{Experimental procedure}

The time-dependent uptake technique used for the measurements reported here has been described in detail elsewhere (Finlayson-Pitts and Pitts, 2000; Klassen et al., 1999; Iraci et al., 2002). The Knudsen cell consists of two Teflon-coated Pyrex chambers separated by a valve, with an aqueous sulfuric acid sample placed in the bottom chamber and cooled by immersion in an alcohol bath. Gaseous $\mathrm{HOBr}$ and water are introduced separately into the top chamber, which has a small aperture leading to a differentially pumped mass spectrometric (MS) detection system (Balzers QMG 421 quadrupole mass spectrometer with electron ionization). The total pressure in the top chamber is kept below 25 mTorr, and the residence time in the top chamber is determined by the size of the escape aperture. During the five warmest experiments on
$45 \mathrm{wt} \% \mathrm{H}_{2} \mathrm{SO}_{4}$, the vapor pressures exceeded 25 mTorr, but even under those conditions, the mean free path was never less than the radius of the escape aperture; this requirement established the upper temperature limit for exposure of $\mathrm{HOBr}$ to the most dilute acid solution. When the valve between the two chambers is opened, loss of the gas-phase species to the surface competes with escape through the aperture and is observed as a decrease in the mass spectrometer signal. The net uptake coefficient, $\gamma$, is defined as the fraction of incident molecules which is lost to the surface.

The number of $\mathrm{HOBr}$ molecules lost to the surface is measured by the change in flow through the escape aperture upon exposing the surface, $F_{O}-F$, where $F_{O}$ and $F$ (molecules s${ }^{-1}$ ) refer to the gas flow rate out of the Knudsen cell before and during exposure to the sample. The number of gas-surface collisions per second is derived from gas kinetic theory as $\bar{c} n A_{s} / 4$, where $\bar{c}$ is the average molecular velocity $\left(\mathrm{cm} \mathrm{s}^{-1}\right), n$ is the density of gas molecules (molecules $\mathrm{cm}^{-3}$ ), and $A_{s}$ is the area of the reactive surface $\left(\mathrm{cm}^{2}\right)$. The gas density, $n$, is determined by the flow into the Knudsen cell and the rate of "collision" with the escape aperture, $n=4 F / \bar{c} A_{h}$, where $A_{h}$ is the area of the aperture $\left(\mathrm{cm}^{2}\right)$. Thus, in terms of the Knudsen cell parameters,

$\gamma=\frac{A_{h}}{A_{s}} \frac{F_{o}-F}{F}$

In its current configuration, the cell can be operated with one of two aperture areas, $0.049 \mathrm{~cm}^{2}$ or $0.018 \mathrm{~cm}^{2}$, and the sulfuric acid has a surface area of $5.7 \mathrm{~cm}^{2}$. Because the MS signal is linear with flow, the signals are used directly in Eq. (1).

The solubility of a species is measured by observing the time dependence of the uptake coefficient. The solute enters the sulfuric acid at a rate determined by liquid-phase diffusion away from the surface and by its solubility and reaction in sulfuric acid. The net uptake coefficient, which represents the difference between sticking and evaporation, decreases as the $\mathrm{HOBr}$ concentration increases in the sulfuric acid. The equation describing the time-dependence of the uptake coefficient is

$\frac{1}{\gamma(t)}=\beta+\left[\frac{4 R T H^{*}}{\bar{c}}\left(\sqrt{\frac{D}{\pi t}}+\sqrt{D k}\right)\right]^{-1}$

where $R\left(\mathrm{Latm} \mathrm{mol}^{-1} \mathrm{~K}^{-1}\right)$ is the gas constant, $T(\mathrm{~K})$ is the temperature of the gas, $H^{*}\left(\mathrm{M} \mathrm{atm}^{1}\right)$ is the Henry's law solubility coefficient, $k$ is the rate constant describing any pseudo-first-order reaction which may occur, and $D\left(\mathrm{~cm}^{2} \mathrm{~s}^{-1}\right)$ is the liquid-phase diffusion coefficient (Finlayson-Pitts and Pitts, 2000; Hanson and Ravishankara, 1993; Worsnop et al., 1989). $\beta$ is an intercept term which includes gas-phase diffusion and accommodation limitations, if any; in the usual notation, $\beta=\Gamma_{g}^{-1}+\alpha^{-1}$. In the absence of reaction, the quantity $H^{*} \sqrt{D}$ is determined from the reciprocal of the slope of a plot of $1 / \gamma$ versus $\sqrt{t}$. To determine $H^{*}$, the liquid-phase diffusion coefficient is calculated from the 
equation $D=c \times T / \eta$, where $c\left(\mathrm{~cm}^{2} \mathrm{cP} \mathrm{s}^{-1} \mathrm{~K}^{-1}\right)$ is a constant that depends on the solvent and on the diffusing species, $T$ $(\mathrm{K})$ is the temperature of the liquid, and $\eta(\mathrm{cP})$ is the viscosity of the liquid. For $\mathrm{HOBr}$ in sulfuric acid, $c$ is estimated as $6.2 \times 10^{-8} \mathrm{~cm}^{2} \mathrm{cP} \mathrm{s}^{-1} \mathrm{~K}^{-1}$ using the approach of Klassen et al. (1998). The sulfuric acid viscosities are calculated from the equations in Williams and Long (1995).

Hypobromous acid is thermally and photolytically unstable, thus it must be prepared shortly before use. Several methods are reported in the literature, and we have used a method that allows some purification of the product mixture before its use. Silver nitrate $(25 \mathrm{~g})$ is dissolved in water $(150 \mathrm{~mL})$ and reacted with excess $\mathrm{Br}_{2}(5 \mathrm{~mL})$. The $\mathrm{HOBr}$ produced is collected by vacuum distillation into $30 \mathrm{wt} \%$ $\mathrm{H}_{2} \mathrm{SO}_{4}$ held at $-40^{\circ} \mathrm{C}$. After several attempts, we devised a preparatory scheme that delivers an adequate supply of gas phase HOBr from this acidic solution to our Knudsen cell apparatus. In brief, a portion of the collected solution is transferred to a bubbler and acidified further to enhance the vapor pressure of $\mathrm{HOBr}$ over the solution. Then the sample is bubbled with helium to remove much of the excess $\mathrm{Br}_{2}$ collected during the distillation. After the solution color has changed from orange to yellow (indicating the removal of the majority of the $\mathrm{Br}_{2}$ ), the bubbler is placed in a dry ice/isopropanol bath. Helium, nitrogen, and other gaseous impurities are pumped off, and the bubbler is allowed to thaw in ice water. Once melted, the vapor over this solution is introduced to the Knudsen cell using only Teflon tubing and fittings. The bubbler is kept in the dark in an ice-water bath during use and can be stored at $\sim 0^{\circ} \mathrm{C}$ in the dark for nearly a week.

The two major isotopes of $\mathrm{HOBr}$ were detected mass spectrometrically at $\mathrm{m} / \mathrm{z}=96$ and 98 . Also present in the gas stream were large amounts of water vapor $(\mathrm{m} / \mathrm{z}=18)$ and several other brominated gases. $\mathrm{Br}_{2}(\mathrm{~m} / \mathrm{z}=160)$ was detected in significant quantities and was greatly reduced by bubbling with helium at the start of each day. Through the course of a day, however, some $\mathrm{Br}_{2}$ did regenerate in solution. $\mathrm{Br}_{2} \mathrm{O}$ (176) and $\mathrm{HBr}(80)$ were also present and varied in relative amount from one batch of $\mathrm{HOBr}$ to the next. In general, the signal from $\mathrm{Br}_{2}$ was comparable to that of $\mathrm{HOBr}$, $\mathrm{Br}_{2} \mathrm{O}$ was roughly $10 \%$ of the signal from $\mathrm{HOBr}$, and $\mathrm{HBr}$ was usually 2-5 times higher than HOBr. Due to the mixture of gases in the $\mathrm{HOBr}$ stream and the dominance of water, only a rough estimate of the $\mathrm{HOBr}$ partial pressures can be made. Assuming an equal mass spectral response from both $\mathrm{HBr}$ and $\mathrm{HOBr}$, comparison of $\mathrm{HOBr}$ signals to those of pure $\mathrm{HBr}$ in test experiments suggests that most of the experiments reported here were conducted between $3 \times 10^{-6}$ and $3 \times 10^{-5}$ Torr of HOBr. Furthermore, flow conditions were varied from experiment to experiment, with the range of $\mathrm{HOBr}$ partial pressures spanning perhaps $2 \times 10^{-7}$ to $6 \times 10^{-5}$ Torr over the full suite of experiments discussed below.

If necessary, additional water was introduced to maintain the vapor pressure of water over the sulfuric acid solution at the experimental temperature, thus preventing evaporation and changes to the composition of the acid. Water pressures often matched the solution water vapor pressure to within $10 \%$, and most were better than $60 \%$. Occasionally, difficulties in setting flow rates led to differences of $100 \%$ or more. A mismatch of $60 \%$ in water pressure may change the surface composition by $\sim 2-3 \mathrm{wt} \% \mathrm{H}_{2} \mathrm{SO}_{4}$.

In the presence of so much water vapor, we cannot ignore the possibility of reactions on wet wall surfaces. To test for changes in $\mathrm{HOBr}$ flow due to the small additional wall surface area once the valve is open, we performed blank exposures on the empty reactor at room temperature and colder. Sometimes we saw very small indications of uptake, much smaller than the uptake due to solubility. Sometimes we saw a transient passivation effect; upon initial exposure $\mathrm{HOBr}$ and $\mathrm{Br}_{2} \mathrm{O}$ were lost to the walls, with possible indications of $\mathrm{Br}_{2}$ production. After just a moment or two of exposure, this effect was no longer present. Each morning, before starting a series of experiments, we flowed the reactant gas stream through the upper, larger portion of the reactor to passivate the wall surfaces. We did not passivate the lower chamber in the presence of sulfuric acid samples, but no difference was seen between measurements made early in the day and those made later on in the series, indicating that the quantity of $\mathrm{HOBr}$ lost to "fresh" walls beneath the valve was negligible.

Temperatures were measured with several K-type thermocouples attached to the outside of the glass cell. One was located at the level of the meniscus, which gave the most reliable results and was used almost exclusively. Temperatures were recorded to $0.1 \mathrm{~K}$ and were calibrated via comparison to the water vapor pressure measurements of Zhang et al. (1993). To do so, a Baratron capacitance manometer was zeroed with the cell evacuated, and then the vapor pressure over the known $\mathrm{H}_{2} \mathrm{SO}_{4} / \mathrm{H}_{2} \mathrm{O}$ solution was measured. The parameterization of Zhang et al. (1993) was used to predict the temperature for the observed vapor pressure, and the thermocouple readings were adjusted to match. This adjustment was always $\leq 3 \mathrm{~K}$, and often $\leq 1 \mathrm{~K}$. Once calibrated, the thermocouple could be used to measure temperature when a combination of gases was present and the water pressure was not known accurately. The last step in determining the temperature of an uptake measurement was to account for drift during an experiment. The coolant bath was stirred between experiments, but due to coupling with the stir bar in the acid solution, stirring had to be halted during exposure. Thus, the temperature of the bath and the solution drifted. For most experiments, the drift was less than $1 \mathrm{~K}$, but for the coldest experiments, a drift of up to $2 \mathrm{~K}$ was observed. The temperatures reported here are the average of the warmest and coldest during the exposure, and uncertainties are $\pm 0.5 \mathrm{~K}$ overall. Between experiments, the sulfuric acid solution was stirred for $\geq 10 \mathrm{~min}$ to regenerate a fresh acid surface.

Sulfuric acid solutions were prepared from concentrated $\mathrm{H}_{2} \mathrm{SO}_{4}$ (Mallinckrodt) and deionized (Millipore) water. Titrations with standard $\mathrm{NaOH}$ solutions identified the acid 

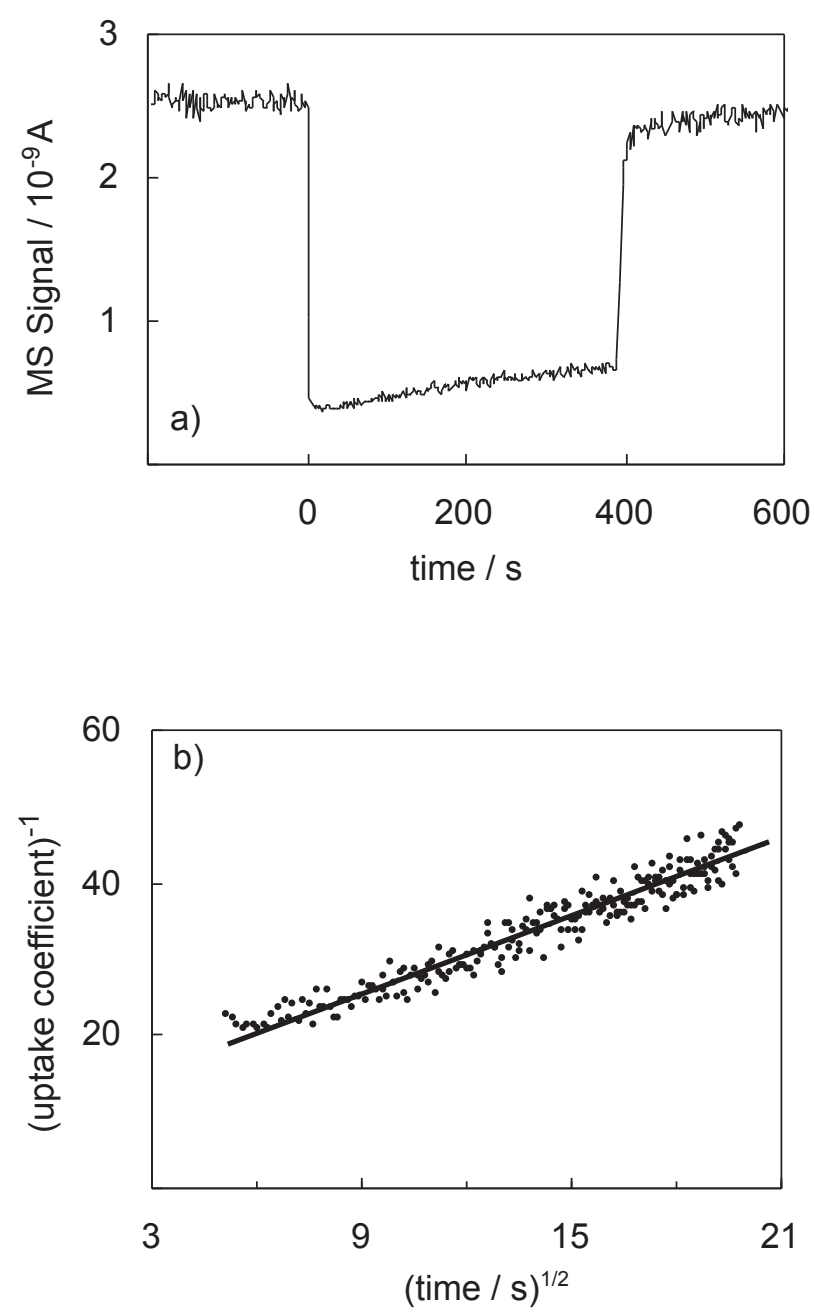

Fig. 1. (a) Mass spectrometer signal as a function of time showing behavior of $\mathrm{HO}^{81} \mathrm{Br}$ upon exposure to $45.3 \mathrm{wt} \% \mathrm{H}_{2} \mathrm{SO}_{4}$ solution at $219.0 \mathrm{~K}$. Exposure was begun at $0 \mathrm{~s}$ and ended at $400 \mathrm{~s}$. Panel (b) Inverse of uptake coefficient as a function of (time $)^{1 / 2}$ and the linear fit which results in values of $H^{*}=6.3 \times 10^{5} \mathrm{M} \mathrm{atm}^{-1}$ and $\beta=10.3$. Because Eq. (2) does not approximate the coupled differential equations well at very short times, data before $6 s^{1 / 2}$ are excluded from the fit.

solutions used here as: $70.1 \pm 0.5,60.7 \pm 0.5,55.2 \pm 0.6$, $45.3 \pm 0.4$, and $43.6 \pm 0.2 \mathrm{wt} \% \mathrm{H}_{2} \mathrm{SO}_{4}$. Solubility measurements on the 45.3 and $43.6 \mathrm{wt} \%$ solutions are reported collectively below as " $45 \mathrm{wt} \%$ ".

\section{Results and discussion}

\subsection{Uptake on aqueous $45 \mathrm{wt} \% \mathrm{H}_{2} \mathrm{SO}_{4}$ solutions}

As shown in Fig. 1, the uptake of $\mathrm{HOBr}$ on $45 \mathrm{wt} \% \mathrm{H}_{2} \mathrm{SO}_{4}$ solutions demonstrated the time-dependent behavior of simple solubility. Panel 1a shows the mass spectrometer signal at $\mathrm{m} / \mathrm{z}=98\left(\mathrm{HO}^{81} \mathrm{Br}\right)$ as a function of time. Exposure to the acid

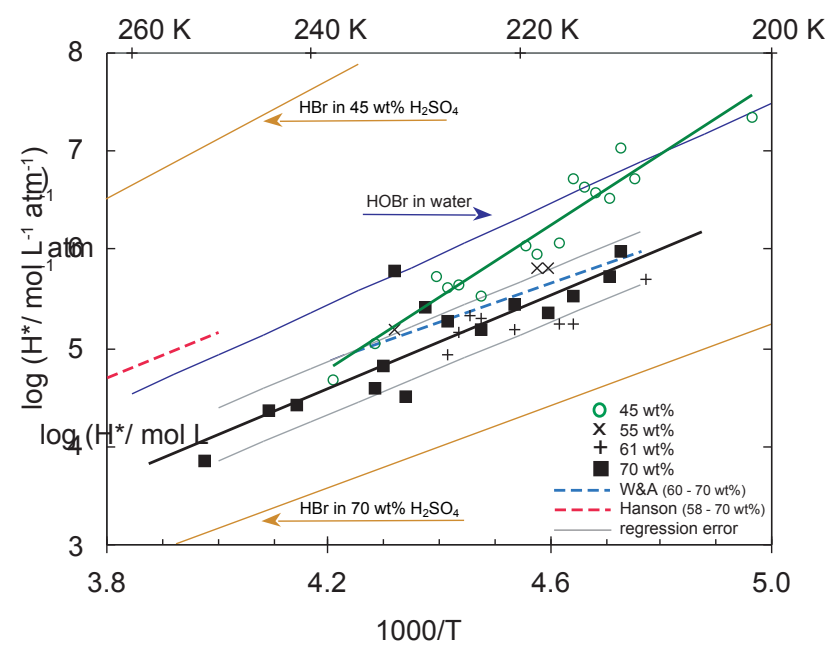

Fig. 2. Log of the effective Henry's law coefficient as a function of inverse temperature. Experimental results for $\mathrm{HOBr}$ solubility in $45 \mathrm{wt} \% \mathrm{H}_{2} \mathrm{SO}_{4}$ are averaged in $1 \mathrm{~K}$ bins and plotted as green circles. The solid green line is the best fit to these data, log $H^{*}=3665 / \mathrm{T}-10.63$. Other $1 \mathrm{~K}$ average results shown are: crosses $(\times)$ for $55 \mathrm{wt} \% \mathrm{H}_{2} \mathrm{SO}_{4}$, plus signs (+) for $61 \mathrm{wt} \%$, and squares for $70 \mathrm{wt} \%$. All data for $55-70 \mathrm{wt} \%$ were then combined in $1 \mathrm{~K}$ intervals; the resulting linear fit is shown as the solid black line (log $\left.H^{*}=2349 / \mathrm{T}-5.27\right)$. The thin gray lines show the best fit plus and minus one standard error of the regression, as explained in the text. For comparison, the results of Waschewsky and Abbatt (1999) for $60-70 \mathrm{wt} \% \mathrm{H}_{2} \mathrm{SO}_{4}$ are shown over their experimental temperature range as the dashed blue line, while the warmer temperature results of Hanson's $58-70 \mathrm{wt} \% \mathrm{H}_{2} \mathrm{SO}_{4}$ solutions are given by the dotted red line at the left side of the figure. Thin brown lines at the top and bottom show the solubility of $\mathrm{HBr}$, as calculated from Sander et al. (2003).

solution was begun at $\mathrm{t}=0 \mathrm{~s}$ and terminated at $\mathrm{t}=400 \mathrm{~s}$. Panel $1 \mathrm{~b}$ shows the inverse of the calculated uptake coefficient, $\gamma$, (Eq. 1) as a function of the square root of exposure time. The linear result is indicative of solubility-driven uptake $(k=0$ in Eq. 2). For this example $\left(45.3 \mathrm{wt} \% \mathrm{H}_{2} \mathrm{SO}_{4}, 219.0 \mathrm{~K}\right)$, the determined Henry's law coefficient was $6.3 \times 10^{5} \mathrm{Matm}^{-1}$. At significantly colder temperatures $(201.5 \mathrm{~K}$, not shown), a value of $2.2 \times 10^{7} \mathrm{M} \mathrm{atm}^{-1}$ was found. For several experiments, the values were confirmed by comparison to the lighter isotope, $\mathrm{HO}^{79} \mathrm{Br}$; these measurements usually agreed within $15 \%$. Results for individual experiments are reported in Table S1, which can be found in the Supplemental Information.

Over thirty experiments were performed on $45 \mathrm{wt} \%$ $\mathrm{H}_{2} \mathrm{SO}_{4}$ and were grouped into $1 \mathrm{~K}$ temperature bins. The average value of $H^{*}$ in each bin is shown by the green circles in Fig. 2. Individual values within a bin were often in excellent agreement, and most bins contained values which agreed within a factor of two. Those with the most measurements sometimes had a spread as large as a factor of four. Also shown in Fig. 2 as the blue solid line is the extrapolated 
(hypothetical) solubility of $\mathrm{HOBr}$ in water. The $298 \mathrm{~K}$ lower limit estimate of $\sim 1900 \mathrm{M} \mathrm{atm}^{-1}$ (Sander, 1999; Blatchley et al., 1992) was combined with the temperature dependence of $\mathrm{HOCl}$ solubility (Huthwelker et al., 1995) as a best approximation.

As expected, $\mathrm{HOBr}$ is more soluble in colder acid solutions. From the slope of the best fit line (log $H^{*}=(3665 \pm 270) / T-(10.63 \pm 1.23)$, where the quoted uncertainties are $1 \sigma$, solid green line), the enthalpy of solution is determined to be $-70.2 \pm 5.2 \mathrm{~kJ} \mathrm{~mol}^{-1}$, and the entropy is $-204 \pm 24 \mathrm{~J} \mathrm{~mol}^{-1} \mathrm{~K}^{-1}$. The latter indicates that during condensation and dissolution, $\mathrm{HOBr}$ loses significantly more entropy than would be expected for simple condensation ( $\sim-85 \mathrm{~J} \mathrm{~mol}^{-1} \mathrm{~K}^{-1}$ from Trouton's Rule) or solvation followed by ionization $\left(\sim-115 \mathrm{~J} \mathrm{~mol}^{-1} \mathrm{~K}^{-1}\right.$, Williams et al., 1995), suggesting considerable ordering of the solvent around the solute. This is consistent with the large negative enthalpy observed as well.

Other mass-to-charge ratios were also monitored during exposure, and behavior of the $\mathrm{HBr}(\mathrm{m} / \mathrm{z}=80), \mathrm{Br}_{2}$ (160), and $\mathrm{Br}_{2} \mathrm{O}$ (176) impurities could be observed. All three trace gases showed uptake into $45 \mathrm{wt} \% \mathrm{H}_{2} \mathrm{SO}_{4}$ solutions at all temperatures studied (201.5-237.9 K).

\subsection{Uptake on aqueous $70 \mathrm{wt} \% \mathrm{H}_{2} \mathrm{SO}_{4}$ solutions}

Exposure of $\mathrm{HOBr}$ to $70 \mathrm{wt} \% \mathrm{H}_{2} \mathrm{SO}_{4}$ solutions at warm temperatures produced uptake curves similar to those obtained for $45 \mathrm{wt} \%$ solutions (see Fig. 1). At colder temperatures, results such as that shown in Fig. 3 were observed. Negative deviation of the reciprocal of the uptake coefficient (circles in panel b) from the expected linear behavior (dashed line) indicates slower solution saturation, suggesting additional uptake processes are contributing beyond simple solubility. This enhanced uptake response was observed for most experiments at temperatures $<224 \mathrm{~K}$ and suggests a reactive process is also contributing to the uptake.

As discussed above, solution-phase reactions of $\mathrm{HOBr}$ with itself and with $\mathrm{HBr}$ are known. For experiments which showed enhanced uptake, we searched for gaseous products. The mass spectrometer signals at $\mathrm{m} / \mathrm{z}=160\left(\mathrm{Br}_{2}\right)$ and $176\left(\mathrm{Br}_{2} \mathrm{O}\right)$ during two types of experiments are shown in Fig. 4. Panel 4a shows the signals for $\mathrm{Br}_{2}$ and $\mathrm{Br}_{2} \mathrm{O}$ during the experiment shown in Fig. 3. Initially, both species are present as impurities in the $\mathrm{HOBr}$ flow. Once exposure begins, $\mathrm{Br}_{2}$ and $\mathrm{Br}_{2} \mathrm{O}$ are generated in solution and released to the gas phase, increasing the mass spectrometer signal. This observation of $\mathrm{Br}_{2}$ production is consistent with Hanson's (2003) report of $\mathrm{Br}_{2}$ production on $80 \mathrm{wt} \% \mathrm{H}_{2} \mathrm{SO}_{4}$; we believe we are the first to report $\mathrm{Br}_{2} \mathrm{O}$ production from sufficiently cold, acidic solutions. When exposure stops near $800 \mathrm{~s}$, both gases return to their previous levels. This liberation of $\mathrm{Br}_{2}$ and $\mathrm{Br}_{2} \mathrm{O}$ was seen only with $70 \mathrm{wt} \% \mathrm{H}_{2} \mathrm{SO}_{4}$ solutions, and then most commonly in the colder temperature regime $(\leq 228 \mathrm{~K})$. Production of $\mathrm{Br}_{2} \mathrm{O}$ was seen in all $70 \mathrm{wt} \%$
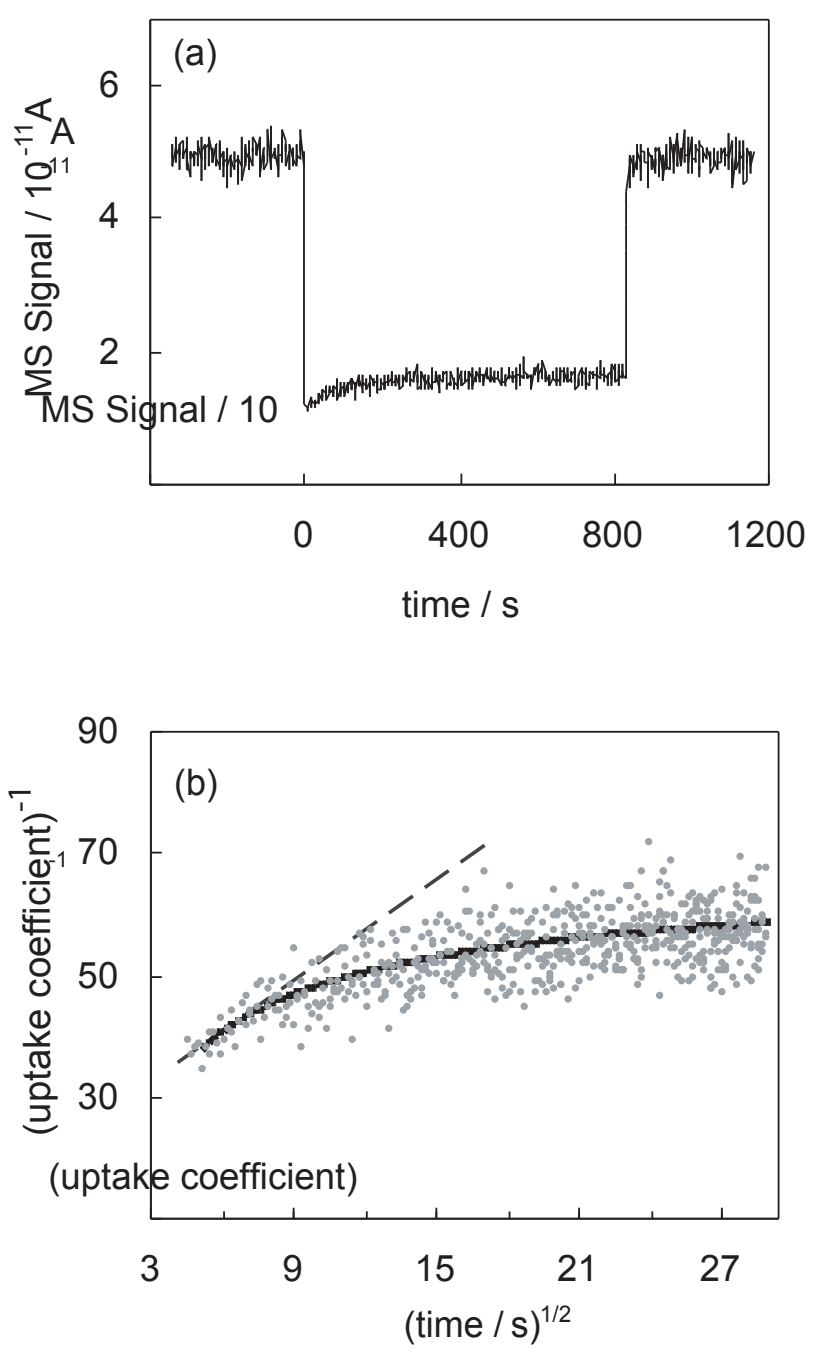

Fig. 3. (a) Mass spectrometer signal as a function of time showing behavior of $\mathrm{HO}^{81} \mathrm{Br}$ upon exposure to $70.1 \mathrm{wt} \% \mathrm{H}_{2} \mathrm{SO}_{4}$ solution at $211.9 \mathrm{~K}$. Exposure was begun at $0 \mathrm{~s}$ and ended at $826 \mathrm{~s}$. Panel (b) Inverse of the uptake coefficient as a function of (time $)^{1 / 2}$. The dashed line shows the least-squares fit to data collected between 6 and $8.3 \mathrm{~s}^{1 / 2}$, which would result in values of $H^{*}=2.7 \times 10^{6} \mathrm{M} \mathrm{atm}^{-1}$ and $\beta=24.1$. The observed deviation from linearity indicates reactive uptake processes in addition to solubility. A three-parameter fit yields $H^{*}=4.3 \times 10^{5} \mathrm{M} \mathrm{atm}^{-1}, k=1.8 \times 10^{-2}$, and $\beta=5.6$, and is shown by the solid black curve.

experiments with $T \leq 228 \mathrm{~K} ; \mathrm{Br}_{2}$ was released from solution in all but two of these cold experiments. The partial pressures of $\mathrm{HOBr}$ employed in these experiments were lower than in many others which did not show product formation. The temperature dependence was clear, but any dependence of $\mathrm{Br}_{2} \mathrm{O}$ or $\mathrm{Br}_{2}$ production on $\mathrm{HOBr}$ pressure alone could not be discerned from the data collected.

For comparison, Fig. $4 \mathrm{~b}$ shows the behavior of $\mathrm{Br}_{2}$ and $\mathrm{Br}_{2} \mathrm{O}$ during the exposure of $\mathrm{HOBr}$ (and impurities) to $45 \mathrm{wt} \% \mathrm{H}_{2} \mathrm{SO}_{4}$ shown in Fig. 1. For clarity, the $\mathrm{Br}_{2} \mathrm{O}$ signal has been magnified by a factor of 2.5. When exposed 

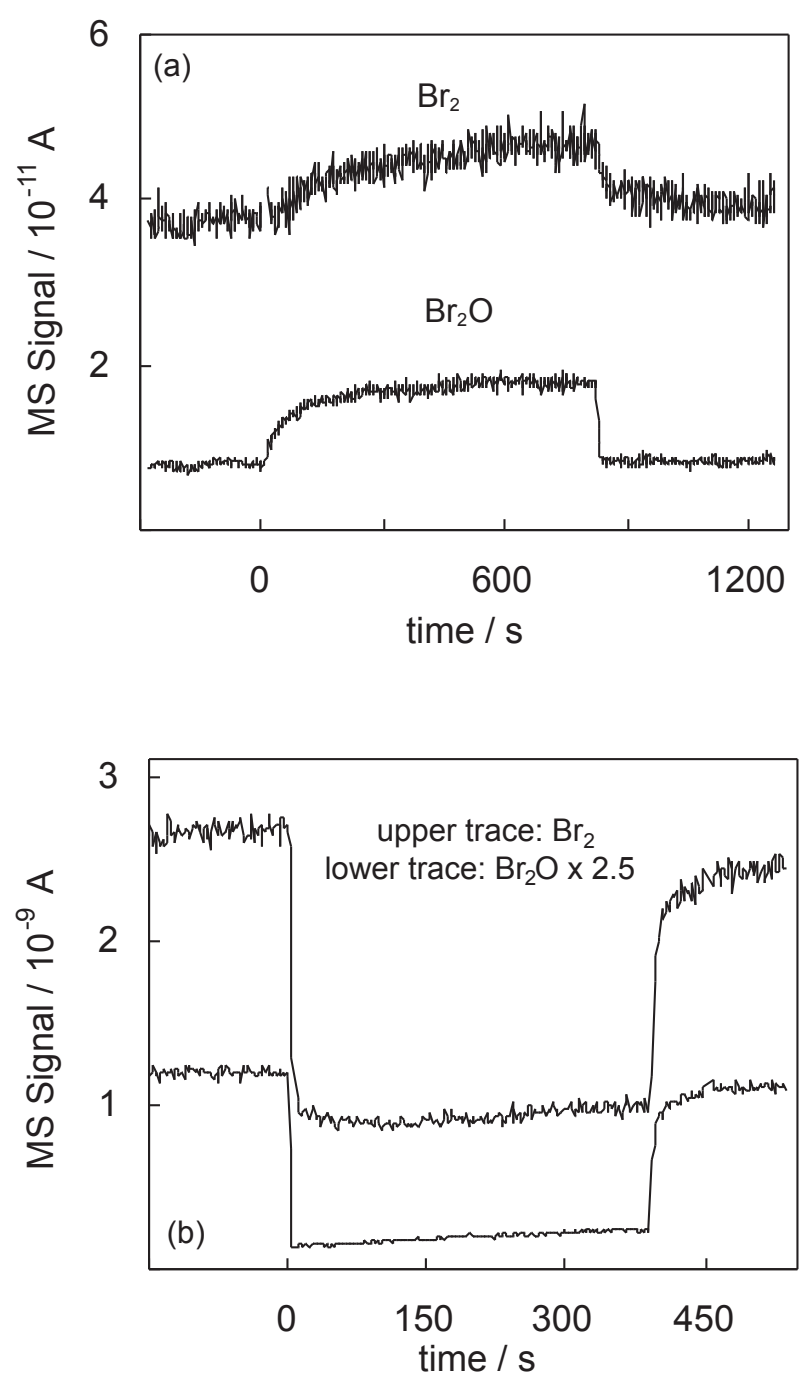

Fig. 4. (a) Mass spectrometer signals as a function of time showing liberation of $\mathrm{Br}_{2}(\mathrm{~m} / \mathrm{z}=160)$ and $\mathrm{Br}_{2} \mathrm{O}(176)$ upon exposure to $70.1 \mathrm{wt} \% \mathrm{H}_{2} \mathrm{SO}_{4}$ at $211.9 \mathrm{~K}$. Panel (b) MS signals showing uptake of the same species during exposure to $45.3 \mathrm{wt} \% \mathrm{H}_{2} \mathrm{SO}_{4}$ at $219.0 \mathrm{~K}$.

to $45 \mathrm{wt} \% \mathrm{H}_{2} \mathrm{SO}_{4}$, it is obvious that $\mathrm{Br}_{2}$ and $\mathrm{Br}_{2} \mathrm{O}$ are both taken up by the solution. Uptake of $\mathrm{Br}_{2} \mathrm{O}$ by sulfuric acid solutions has also been reported by previous investigators (Waschewsky and Abbatt, 1999; Hanson, 2003). If uptake of $\mathrm{Br}_{2} \mathrm{O}$ leads to $\mathrm{HOBr}$ production in-situ, we may be underestimating $H^{*}$. From the experiment shown in Figs. 1 and $4 \mathrm{~b}$, we estimate this uncertainty to be on the order of $25 \%$.

Why is reaction only clearly observed for exposure of $\mathrm{HOBr}$ to $70 \mathrm{wt} \% \mathrm{H}_{2} \mathrm{SO}_{4}$ solutions with $T \leq 228 \mathrm{~K}$ ? An answer can be found by analogy in the case of $\mathrm{HOBr}+\mathrm{HCl}$, as measured by Waschewsky and Abbatt (1999) as a function of both temperature and wt $\% \mathrm{H}_{2} \mathrm{SO}_{4}$. Those authors found that the second-order rate constant increased with acidity at each temperature studied and that the temperature effect was least pronounced in $70 \mathrm{wt} \%$ solution. Thus, we are observing an increase in reaction rate with increased acidity (due to an increasing value of the rate constant $k$ ) and with decreased temperature (due to increased solubility).

Due to the competing reactions of $\mathrm{HOBr}$ in the $70 \mathrm{wt} \%$ $\mathrm{H}_{2} \mathrm{SO}_{4}$ system, the Henry's law coefficient must be extracted from a three-parameter $\left(H^{*}, k\right.$, and $\left.\beta\right)$ fit of Eq. (2) to the data, once again calculating diffusion constants as described by Klassen et al. (1998). For the example shown in Fig. $3\left(70.1 \mathrm{wt} \% \mathrm{H}_{2} \mathrm{SO}_{4}, T=211.9 \mathrm{~K}\right)$, $H^{*}=4.3 \times 10^{5} \mathrm{M} \mathrm{atm}^{-1}, k=1.8 \times 10^{-2}$, and $\beta=5.6$. The solid curve in Fig. $3 \mathrm{~b}$ shows the resulting fit. Please see the Appendix for a brief discussion of the non-linear fitting procedure.

Values of $H^{*}$ extracted from a three-parameter fit agreed very well with those from a linear fit for $45 \mathrm{wt} \%$ solutions and for $70 \mathrm{wt} \%$ solutions where the parameter $k$ was found to be small. For significant values of $k$, such as in the example shown in Fig. 3, the $H^{*}$ value determined from the three-parameter fit was a factor of 3-10 lower than the value determined from a linear fit through a somewhat arbitrary, early portion of the data. Fitting the full equation (Eq. 2) was less susceptible to bias, and thus was trusted as a method less prone to error. The values reported throughout this manuscript are those determined from three-parameter fits of entire data sets; in many cases, $k=0$.

Experiments were performed over the range of 211.9$251.6 \mathrm{~K}$, resulting in nearly forty determinations of $H^{*}$ in $70 \mathrm{wt} \% \mathrm{H}_{2} \mathrm{SO}_{4}$ as a function of temperature. These results were averaged in $1 \mathrm{~K}$ bins and are shown as the solid squares (ם) in Fig. 2. Once again, the solubility of $\mathrm{HOBr}$ is inversely dependent on temperature, but with a different slope than that seen for $45 \mathrm{wt} \% \mathrm{H}_{2} \mathrm{SO}_{4}$ solutions (log $H^{*}=(2419 \pm 381) / \mathrm{T}-(5.55 \pm 1.67)$, not shown $)$. These parameters result in values of $\Delta H=-46.3 \pm 7.3 \mathrm{~kJ} \mathrm{~mol}^{-1}$ and $\Delta S=-106 \pm 32 \mathrm{~J} \mathrm{~mol}^{-1} \mathrm{~K}^{1}$. At temperatures colder than $\sim 213 \mathrm{~K}$, the solubility of $\mathrm{HOBr}$ in $45 \mathrm{wt} \% \mathrm{H}_{2} \mathrm{SO}_{4}$ is noticeably larger than in $70 \mathrm{wt} \% \mathrm{H}_{2} \mathrm{SO}_{4}$.

The fitting parameter $k$ represents the additional loss of $\mathrm{HOBr}$ due to reaction in $70 \mathrm{wt} \% \mathrm{H}_{2} \mathrm{SO}_{4}$ solution. We do not believe it corresponds to an elementary rate constant in our experiments. Its value increases with decreasing temperature $(\log k=(2192 \pm 449) / \mathrm{T}-(12.4 \pm 2.0)$ in $1 \mathrm{~K}$ bins $)$, suggesting that $k$ is driven by the solubility of the reaction partner(s), rather than by the rate constant of the elementary reaction. The comparable signals for the two product species, as shown in Fig. 4a, suggest that Reactions 1 and 3 are proceeding at similar rates, assuming similar solubilities and MS sensitivities for each. Because $\mathrm{HOBr}$ is $\sim 15$ times more soluble than $\mathrm{HBr}$ in $70 \mathrm{wt} \% \mathrm{H}_{2} \mathrm{SO}_{4}$, our solutions should have contained 3-8-fold more $\mathrm{HOBr}$ than $\mathrm{HBr}$, suggesting that the rate constant for $\mathrm{HOBr}+\mathrm{HBr}$ may be roughly 3-8 times larger than that for $\mathrm{HOBr}+\mathrm{HOBr}$. 


\subsection{Uptake on aqueous 55 and $61 \mathrm{wt} \% \mathrm{H}_{2} \mathrm{SO}_{4}$ solutions}

Several solubility measurements were also made on 55 and $61 \mathrm{wt} \% \mathrm{H}_{2} \mathrm{SO}_{4}$ solutions. These data indicated uptake due to simple solubility in most cases, with a few observations suggestive of reaction but not definitive. The solubility values are shown as $1 \mathrm{~K}$ averages in Fig. 2, where data for $55 \mathrm{wt} \% \mathrm{H}_{2} \mathrm{SO}_{4}$ are represented by crosses $(\times)$, and those for $61 \mathrm{wt} \%$ are marked by plus signs (+). As found by others (Waschewsky and Abbatt, 1999; Hanson, 2003), we do not observe a significant acidity dependence for solutions in this regime. In this respect, $\mathrm{HOBr}$ is quite different from $\mathrm{HBr}$, which is approximately 4 orders of magnitude more soluble in $45 \mathrm{wt} \% \mathrm{H}_{2} \mathrm{SO}_{4}$ than in $70 \mathrm{wt} \%$ (Sander et al., 2003). A non-zero $\left(10^{-6}-10^{-3}\right) k$ parameter was occasionally found in the 55 and $61 \mathrm{wt} \%$ experiments, but no pattern or clear temperature trend was demonstrated.

3.4 Combined results for uptake on 55-70 wt $\% \mathrm{H}_{2} \mathrm{SO}_{4}$ solutions

All values for $H^{*}$ in $55-70 \mathrm{wt} \% \mathrm{H}_{2} \mathrm{SO}_{4}$ solution were averaged together in $1 \mathrm{~K}$ temperature intervals, and the leastsquares fit is shown in Fig. 2 as the solid black line $\left(\log H^{*}=(2349 \pm 280) / \mathrm{T}-(5.27 \pm 1.24)\right)$. From the slope of this line, an enthalpy of solvation of $-45.0 \pm 5.4 \mathrm{~kJ} \mathrm{~mol}^{-1}$ was determined $\left(\Delta S=-101 \pm 24 \mathrm{~J} \mathrm{~mol}^{-1} \mathrm{~K}^{-1}\right)$. For comparison, uptake of $\mathrm{HOCl}$ into $60 \mathrm{wt} \% \mathrm{H}_{2} \mathrm{SO}_{4}$ has $\Delta H=-42.1 \mathrm{~kJ} \mathrm{~mol}^{-1}$ (and $\Delta S=-109 \mathrm{~J} \mathrm{~mol}^{-1} \mathrm{~K}^{-1}$; Huthwelker et al., 1995), indicating that our observed temperature dependence for $\mathrm{HOBr}$ uptake into 55-70 wt $\% \mathrm{H}_{2} \mathrm{SO}_{4}$ solutions is quite similar. For uptake of $\mathrm{HBr}$ into $66 \mathrm{wt} \% \mathrm{H}_{2} \mathrm{SO}_{4}$, Williams et al. (1995) found $\Delta H=-42.3 \mathrm{~kJ} \mathrm{~mol}^{-1}$ and estimated $\Delta S=-113 \mathrm{~J} \mathrm{~mol}^{-1} \mathrm{~K}^{-1}$. Furthermore, the present value of $\Delta H=45.0 \mathrm{~kJ} \mathrm{~mol}^{-1}$ is midway between the two reported values currently available for $\mathrm{HOBr}:-52.3 \mathrm{~kJ} \mathrm{~mol}^{-1}$ measured by Hanson (2003), and $-38 \mathrm{~kJ} \mathrm{~mol}^{-1}$ reported by Waschewsky and Abbatt (1999, hereafter referred to as W\&A). Thus, our measurement closely confirms the averaged enthalpy of solvation $\left(-45.2 \mathrm{~kJ} \mathrm{~mol}^{-1}\right)$ used by Hanson in his parameterization, which is shown as the dotted red line at warmer temperatures in Fig. 2. The entropy value determined here for $\mathrm{HOBr}$ uptake into $55-70 \mathrm{wt} \%$ $\mathrm{H}_{2} \mathrm{SO}_{4}\left(\Delta S=-101 \mathrm{~J} \mathrm{~mol}^{-1} \mathrm{~K}^{-1}\right)$ is less negative than for methanol $\left(-134 \mathrm{~J} \mathrm{~mol}^{-1} \mathrm{~K}^{-1}\right.$; Iraci et al., 2002) and acetone $\left(-172 \mathrm{~J} \mathrm{~mol}^{-1} \mathrm{~K}^{-1}\right.$; Klassen et al., 1999) uptake into $45-70 \mathrm{wt} \%$ sulfuric acid solutions.

Also shown in Fig. 2 (dashed blue line) is the result of W\&A from measurements conducted at 213-238 K; our findings match theirs extremely well. The narrow gray lines show the standard error of the regression line through our data, where $\sigma=0.264=\sqrt{(N-2)^{-1} \Sigma\left(y_{\text {expt }}-y_{f i t}\right)^{2}}$. Our study includes measurements which overlap the temperature regimes of both previous studies, and our results are considerably closer to those of W\&A. Hanson attributes the differ- ence between his values and those of W\&A to differences in experimental method. The W\&A technique requires an estimate of the liquid phase diffusion constant, as does the current measurement. Thus, our measurements and those of W\&A could be argued to be low due to an inadequacy in calculating $D$. However, previous studies in our apparatus (Iraci et al., 2002; Williams et al., 1995) have shown identical results for two different techniques, one requiring an estimate of $D$ and one using an approach similar to that of Hanson (2003), i.e., a method which measures the equilibrium vapor pressure over a solution and requires no presumption about the liquid-phase diffusion constant. Thus, we feel confident using the time-dependent uptake technique presented here and believe the estimated values of $D$ to be sufficiently accurate. Unfortunately, the complementary method could not be employed in the present study, as a pure sample of $\mathrm{HOBr}$ could not be obtained. To raise the present $H^{*}$ values to meet those of Hanson (2003), $\sqrt{D}$ would need to be lowered by a factor of 10 , which implies our $D$ values are incorrect by two orders of magnitude. Such an error seems highly unlikely, as $D$ values have been directly measured for $\mathrm{HBr}$ and similar species in the acidity range considered here (Klassen et al., 1998). One possible explanation for the high solubility values reported by Hanson (2003) is uptake enhancement due to reaction with impurities in the $\mathrm{HOBr}$ source, such as those observed in the present work and discussed by Hanson (2003).

\section{Stratospheric implications}

Not only is the solubility of $\mathrm{HOBr}$ in aqueous sulfuric acid solutions substantial, but we have observed reactions producing volatile brominated gases which suggest that uptake of $\mathrm{HOBr}$ into acidic aerosol particles may not saturate. If the reactions observed under laboratory conditions also occur in the atmosphere, production of $\mathrm{Br}_{2} \mathrm{O}, \mathrm{Br}_{2}$, and by analogy $\mathrm{BrCl}$, will continue as long as source gases are available. In this section we calculate the solution-phase concentrations, estimate the relative rates of each reaction channel (R 1-3), and assess the role of $\mathrm{HOBr}$ solution-phase chemistry in the activation of chlorine in both the contemporary lower stratosphere (LS) and a future LS affected by climate change.

Our measurements allow calculation of $[\mathrm{HOBr}]$, where square brackets denote particle-phase concentration in moles per liter. Because $[\mathrm{HOBr}]$ increases linearly with $\mathrm{HOBr}$ mixing ratio, aerosols contain an order of magnitude more dissolved $\mathrm{HOBr}$ at night, when $\mathrm{HOBr}$ becomes the dominant bromine species. See Table 1. Due to uncertainties in future stratospheric bromine levels (Montzka et al., 2003; Hileman, 2005), mixing ratios of $\mathrm{HOBr}$ and $\mathrm{HBr}$ are held constant in this example. In a future scenario, as chlorine loading and temperature decrease, water vapor increases, and sulfuric acid concentration drops, $[\mathrm{HOBr}]$ nearly doubles. In contrast, $[\mathrm{HCl}]$ increases by an order of magnitude and 
Table 1. HOBr Heterogeneous Chemistry in Lower Stratospheric Aerosols.

\begin{tabular}{|c|c|c|c|c|c|}
\hline & Current Daytime & Current Nighttime & Future Daytime & Future Nighttime & References \& Notes \\
\hline Temperature $(\mathrm{K})$ & 210 & 210 & 205 & 205 & 100 mbar; $15-16 \mathrm{~km}$ \\
\hline Water (g) (ppm) & 4 & 4 & 5 & 5 & est. from Rosenlof et al. (2001) \\
\hline Aerosol composition (wt $\% \mathrm{H}_{2} \mathrm{SO}_{4}$ ) & 66 & 66 & 60 & 60 & Steele and Hamill (1981) \\
\hline $\mathrm{HOBr}(\mathrm{g})(\mathrm{ppt})$ & 1 & 10 & 1 & 10 & \\
\hline $\mathrm{HBr}(\mathrm{g})(\mathrm{ppt})$ & 2 & 2 & 2 & 2 & Johnson et al. (1995) \\
\hline $\mathrm{HCl}(\mathrm{g})(\mathrm{ppb})$ & 1.5 & 1.5 & 1 & 1 & \\
\hline$H^{*} \mathrm{HOBr}\left(\mathrm{mol} \mathrm{L}^{-1} \mathrm{~atm}^{-1}\right)$ & $8.2 \times 10^{5}$ & $8.2 \times 10^{5}$ & $1.5 \times 10^{6}$ & $1.5 \times 10^{6}$ & this work \\
\hline$H^{*} \mathrm{HBr}\left(\mathrm{mol} \mathrm{L}^{-1} \mathrm{~atm}^{-1}\right)$ & $3.2 \times 10^{5}$ & $3.2 \times 10^{5}$ & $8.1 \times 10^{6}$ & $8.1 \times 10^{6}$ & Sander et al. (2003) \\
\hline$H^{*} \mathrm{HCl}\left(\mathrm{mol} \mathrm{L}^{-1} \mathrm{~atm}^{-1}\right)$ & $1 \times 10^{4}$ & $1 \times 10^{4}$ & $1.3 \times 10^{5}$ & $1.3 \times 10^{5}$ & Wexler and Clegg $(2002)^{a}$ \\
\hline$[\mathrm{HOBr}]\left(\mathrm{mol} \mathrm{L}^{-1}\right)$ & $8.1 \times 10^{-8}$ & $8.1 \times 10^{-7}$ & $1.5 \times 10^{-7}$ & $1.5 \times 10^{-6}$ & \\
\hline$[\mathrm{HBr}]\left(\mathrm{mol} \mathrm{L}^{-1}\right)$ & $6.2 \times 10^{-8}$ & $6.2 \times 10^{-8}$ & $1.6 \times 10^{-6}$ & $1.6 \times 10^{-6}$ & \\
\hline$[\mathrm{HCl}]\left(\mathrm{mol} \mathrm{L}^{-1}\right)$ & $1.5 \times 10^{-6}$ & $1.5 \times 10^{-6}$ & $1.3 \times 10^{-5}$ & $1.3 \times 10^{-5}$ & \\
\hline$k$ for $\mathrm{HOBr}+\mathrm{HOBr}\left(\mathrm{L} \mathrm{mol}^{-1} \mathrm{~s}^{-1}\right)$ & $2.3 \times 10^{5}$ & $2.3 \times 10^{5}$ & $1.5 \times 10^{3}$ & $1.5 \times 10^{3}$ & $=k(\mathrm{HBr}) / 8$ \\
\hline$k$ for $\mathrm{HOBr}+\mathrm{HBr}\left(\mathrm{L} \mathrm{mol}^{-1} \mathrm{~s}^{-1}\right)$ & $1.8 \times 10^{6}$ & $1.8 \times 10^{6}$ & $1.2 \times 10^{4}$ & $1.2 \times 10^{4}$ & $=k(\mathrm{HCl}) * 3$ \\
\hline$k$ for $\mathrm{HOBr}+\mathrm{HCl}\left(\mathrm{L} \mathrm{mol}^{-1} \mathrm{~s}^{-1}\right)$ & $6.1 \times 10^{5}$ & $6.1 \times 10^{5}$ & $4.0 \times 10^{3}$ & $4.0 \times 10^{3}$ & Hanson (2003) \\
\hline Rate for $\mathrm{HOBr}+\mathrm{HOBr}\left(\mathrm{molL}^{-1} \mathrm{~s}^{-1}\right)$ & $1.5 \times 10^{-9}$ & $1.5 \times 10^{-7}$ & $3.5 \times 10^{-11}$ & $3.5 \times 10^{-9}$ & \\
\hline Rate for $\mathrm{HOBr}+\mathrm{HBr}\left(\mathrm{mol} \mathrm{L}^{-1} \mathrm{~s}^{-1}\right)$ & $9.2 \times 10^{-9}$ & $9.2 \times 10^{-8}$ & $2.9 \times 10^{-9}$ & $2.9 \times 10^{-8}$ & \\
\hline Rate for $\mathrm{HOBr}+\mathrm{HCl}\left(\mathrm{mol} \mathrm{L}^{-1} \mathrm{~s}^{-1}\right)$ & $7.3 \times 10^{-8}$ & $7.3 \times 10^{-7}$ & $8.1 \times 10^{-9}$ & $8.1 \times 10^{-8}$ & \\
\hline Total rate for $\mathrm{HOBr}+\mathrm{HX}\left(\mathrm{mol} \mathrm{L}^{-1} \mathrm{~s}^{-1}\right)$ & $8.4 \times 10^{-8}$ & $9.7 \times 10^{-7}$ & $1.1 \times 10^{-8}$ & $1.1 \times 10^{-7}$ & \\
\hline $\mathrm{HOBr}$ loss which leads to $\mathrm{BrCl}$ production & $87 \%$ & $75 \%$ & $73 \%$ & $71 \%$ & \\
\hline
\end{tabular}

${ }^{a} H^{*}$ value in third and fourth columns estimated from lowest relative humidity possible with AIM model (58 wt $\left.\%\right)$. $H^{*}$ value in first two columns taken from AIM and reduced by $\sim 7 \times$, as seen by Williams and Golden (1993) and Hanson and Ravishankara (1993) for increasing $\mathrm{H}_{2} \mathrm{SO}_{4}$ by $8 \mathrm{wt} \%$.

$[\mathrm{HBr}]$ increases by a factor of $\sim 25$. The near independence of $\mathrm{HOBr}$ solubility on acidity results in smaller increases in $[\mathrm{HOBr}]$ as particles become less acidic. In the future nighttime scenario, $\mathrm{HBr}$ and $\mathrm{HOBr}$ solution concentrations are nearly equal.

In each of the four cases, we wish to evaluate how much $\mathrm{HOBr}$ will react with each possible partner. To do so, rate constants are needed. Only $k$ values for $\mathrm{HOBr}+\mathrm{HCl}$ have been previously reported (Hanson, 2003; Waschewsky and Abbatt, 1999), although Abbatt (1995) does give a lower limit for $k(\mathrm{HOBr}+\mathrm{HBr})$ at one set of experimental conditions. The parameterization of Hanson (2003) for $k(\mathrm{HOBr}+\mathrm{HCl})$ as a function of temperature and $\mathrm{wt} \% \mathrm{H}_{2} \mathrm{SO}_{4}$ was used to calculate rate constants for that reaction, and the rate constant for $\mathrm{HOBr}+\mathrm{HBr}$ was presumed to be three times larger, as estimated from measurements in aqueous solution (Beckwith et al., 1996; Wang et al., 1994) and in $70 \mathrm{wt} \% \mathrm{H}_{2} \mathrm{SO}_{4}$ at $228 \mathrm{~K}$ (Abbatt, 1995). Based on our experimental observations of approximately equal production of $\mathrm{Br}_{2} \mathrm{O}$ and $\mathrm{Br}_{2}$ (discussed above), we presume in the calculations to follow that $k(\mathrm{HOBr}+\mathrm{HOBr})$ is one-eighth the size of $k(\mathrm{HOBr}+\mathrm{HBr}$ ). Since the rate $=k[\mathrm{HOBr}][\mathrm{HX}]$ (where $\mathrm{X}=\mathrm{OBr}, \mathrm{Br}$, or $\mathrm{Cl}$ ) for reactions which occur throughout a particle, we can determine rates for the three channels based on the calculated solution concentrations and estimated val- ues of $k$. We note that this may not be strictly true for the fast reaction of $\mathrm{HOBr}$ with $\mathrm{HBr}$, but it provides a rough comparison of the relative importance of different reaction partners.

As shown in Table 1, reactions of $\mathrm{HOBr}$ with itself and with $\mathrm{HBr}$ will be minor channels for current daytime conditions, when $\mathrm{HOBr}$ levels are low. Reaction of $\mathrm{HOBr}$ with $\mathrm{HCl}$ will account for $\sim 87 \%$ of the solution phase reactivity. At night, the loss of $\mathrm{HOBr}$ to self-reaction increases 100fold, and the fraction of $\mathrm{HOBr}$ reaction that leads to $\mathrm{BrCl}$ production drops to $75 \%$. However, the increased [HOBr] leads to an increase in the absolute rate of $\mathrm{BrCl}$ production. Thus, increasing $[\mathrm{HOBr}]$ increases the rate of chlorine activation despite the diversion of a larger fraction of $\mathrm{HOBr}$ to the self-reaction pathway.

At night, $\mathrm{HOBr}$ reaction with $\mathrm{HCl}$ could generate 40 50 molecules of $\mathrm{BrCl}$ per $\mathrm{cm}^{3}$ per second, assuming an aerosol volume density of $1 \times 10^{-13} \mathrm{~cm}^{3} \mathrm{~cm}^{-3}$ and no diffusion limitations. If a significant portion was liberated to the gas phase, by morning $\sim 0.5 \mathrm{ppt} \mathrm{BrCl}$ could be present, leading to a small pulse of active chlorine at dawn. Current LS daytime conditions would lead to $\sim 4-5$ molecule $\mathrm{BrCl}$ produced per $\mathrm{cm}^{3}$ per second, for an integrated daily production of $\sim 0.55 \mathrm{ppt} \mathrm{BrCl}$. To compare this activation process to the rate for $\mathrm{Cl}$ activation via $\mathrm{HCl}+\mathrm{OH}$ in the gas phase, we calculate a daily estimate of $25 \mathrm{ppt}$ 
of active chlorine for $12 \mathrm{~h}$ of sunlight with the rate taken from Sander et al. (2003) $\left(\sim 2 \times 10^{3}\right.$ molecule $\mathrm{cm}^{-3} \mathrm{~s}^{-1}$ if $[\mathrm{OH}]=1 \times 10^{6}$ molecule $\left.\mathrm{cm}^{-3}\right)$. Thus the heterogeneous activation route can be seen to be minor on a daily basis under background aerosol conditions, as discussed by others (Hanson, 2003; Waschewsky and Abbatt, 1999). Nonetheless, if a precise understanding of active chlorine is required at sunrise, this mechanism should be considered. And if aerosol volumes were increased 50- to 100 -fold due to volcanic injection, enhanced $\mathrm{Cl}$ activation via $\mathrm{HOBr}$ heterogeneous chemistry would need to be re-assessed.

For wetter, colder future conditions, the aerosol acidity is reduced, leading to strongly reduced rate constants. This decreases all pathways for $\mathrm{HOBr}$ loss and reduces the rate of $\mathrm{BrCl}$ production by a factor of roughly nine in the future scenario considered here. This strong sensitivity to aerosol composition points to a possible enhanced role of this process under conditions where sulfate aerosols are more concentrated than $\sim 65 \mathrm{wt} \% \mathrm{H}_{2} \mathrm{SO}_{4}$. Thus, chlorine activation via $\mathrm{HOBr}$ heterogeneous chemistry may occur under strongly acidic (warm, dry) conditions, or under conditions of enhanced stratospheric aerosol loading. It is unlikely that any significant perturbation of $\mathrm{HOBr}$ will occur, as the formation of $\mathrm{HOBr}$ via $\mathrm{BrONO}_{2}$ hydrolysis is faster (Lary et al., 1996) than loss via heterogeneous reaction. It must be stressed, however, that these results are highly dependent on the presumed second order rate constants, and further measurements of those values would greatly improve the accuracy and relevance of these illustrative calculations.

\section{Conclusions}

The solubility of hypobromous acid has been measured in cold $\mathrm{H}_{2} \mathrm{SO}_{4} / \mathrm{H}_{2} \mathrm{O}$ solutions representative of stratospheric sulfate aerosols. For the conditions studied here (45-70 wt $\%$ $\mathrm{H}_{2} \mathrm{SO}_{4}, 201-252 \mathrm{~K}$ ), the effective Henry's law coefficient, $H^{*}$, ranges from $10^{4}-10^{7} \mathrm{~mol} \mathrm{~L}^{-1} \mathrm{~atm}^{-1}$, with little acidity dependence at temperatures warmer than $\sim 213 \mathrm{~K}$. HOBr solubility in these solutions was similar to that expected in pure water, which may explain the absence of an acidity effect on solubility. Our results span the temperature gap between previous studies and show excellent agreement with the work of Waschewsky and Abbatt (1999). The enthalpy of solution for $\mathrm{HOBr}$ dissolving in $55-70 \mathrm{wt} \% \mathrm{H}_{2} \mathrm{SO}_{4}$ was found to be $-45.0 \pm 5.4 \mathrm{~kJ} \mathrm{~mol}^{-1}$. The relative independence of solubility on acidity implies that heterogeneous chemistry involving $\mathrm{HOBr}$ will be more important (relative to processes involving $\mathrm{HBr}$ and other strong acids) under conditions which favor more acidic particles, as the solubility of $\mathrm{HOBr}$ will not decrease significantly.

\section{Appendix: Non-linear data fitting procedure}

Each exposure of $\mathrm{HOBr}$ to a sulfuric acid solution produces a time trace of mass spectrometer signals which are proportional to gas partial pressures. These signals are converted to time-varying uptake coefficient values, $\gamma$, via Eq. (1). Each set of $\gamma$ values contains information about the solubility of $\mathrm{HOBr}$ and its irreversible reaction(s) in solution. In this study, each data set was fit with the three-parameter nonlinear equation (Eq. 2) which approximates the coupled differential equations describing dissolution and reaction of a gas in a planar liquid (Danckwerts, 1970).

Estimates for the parameters $\left(H^{*}, \beta, k\right)$ were found using a minimization program written for MATLAB by a team of students at San Jose State University (SJSU). Using nonlinear, multivariate methods, the parameter values were found by minimizing the sum of the squared errors (SSE) between the equation and the data. Since $k$ is typically small and is sometimes zero, it is reasonable to assume $k=0$ and solve the reduced (linear) equation to generate a starting estimate for the other two parameters. The minimum SSE was found via a numerical search method similar to simulated annealing.

Because all three parameters must be non-negative, we cannot assume that these parameter estimates follow a Normal distribution, and thus the standard methods for computing confidence intervals cannot be used. Instead, bootstrap methods were used to determine $95 \%$ confidence limits for the unknown parameters.

Lastly, a protocol was developed to objectively identify suspicious or biased data sets. Three tests were applied to the residuals (the difference between each data point and the value calculated from the best-fit parameters). The first identifies points beyond three standard deviations away from the mean of the residuals. The second test highlights any series of nine points on one side of the mean. Such a series may be a signal of unsteadiness in the laboratory process. The last test seeks two out of three consecutive points beyond two standard deviations on the same side of the mean. Each of these events has $<0.5 \%$ probability of occurring in a Normally distributed data set, thus experiments which displayed more events than expected (based on the number of points in each set) were discarded. In the present case, five data sets were excluded from further analysis based on these results.

The parameter values determined with the SJSU MATLAB code were checked against values determined with a separate program written using the statistical software package S-PLUS and its function specifically designed for minimization of non-linear equations. The parameter estimates found using S-PLUS and those found by MATLAB differed by less than one percent. A number of the parameter sets were also compared to values found with the Kaleidagraph software package, and excellent agreement was also obtained.

The MATLAB program used in this work was developed under the supervision of Prof. Steven Crunk as part 
of the Center for Applied Mathematics and Computer Science (CAMCOS, Prof. Timothy Hsu, Director) student research program in the SJSU Department of Mathematics. Team members Greg Holsclaw, Eleanore Jehung, Sylvia Law, Chingchia Ly, Joe Metz, and Tracy Skovmand (all SJSU students) performed the work. Funding for the project was provided by the Henry Woodward Fund.

Acknowledgements. The authors are grateful to T. Benter, R. Schmitt and J. Bottaro for assistance with $\mathrm{HOBr}$ synthesis and to S. Crunk and the CAMCOS program of the Department of Mathematics and Computer Science at San Jose State University for the fitting program discussed in the Appendix. Helpful discussions with K. Drdla, J. Podolske, G. Hallar and B. Schmid contributed to this work. Comments from J. Adams and an anonymous reviewer are gratefully acknowledged. This study was funded by NASA through the continued support of the Upper Atmosphere Research Program (M. Kurylo, program manager) and the Atmospheric Effects of Aviation Program (R. Friedl and R. Lawrence, program managers). Experimental data was collected in the Molecular Physics Laboratory at SRI International. RRM was supported by a National Research Council Associateship, and SFMA was funded through the Camille and Henry Dreyfus Foundation. TAR was supported by the NSF Research Experience for Undergraduates program.

Edited by: J. N. Crowley

\section{References}

Abbatt, J. P. D.: Interactions of $\mathrm{HBr}, \mathrm{HCl}$, and $\mathrm{HOBr}$ with supercooled sulfuric acid solutions of stratospheric composition, J. Geophys. Res., 100, 14 009-14 017, 1995.

Barrie, L. A. and Barrie, J. M.: Chemical components of lower tropospheric aerosols in the high Arctic: Six years of observations, J. Atmos. Chem., 11, 211-226, 1990.

Beckwith, R. C., Wang, T. X., and Margerum, D. W.: Equilibrium and kinetics of bromine hydrolysis, Inorg. Chem., 35, 995-1000, 1996.

Blatchley III, E. R., Johnson, R. W., Alleman, J. E., and McCoy, W. F.: Effective Henry's law constants for free chlorine and free bromine, Wat. Res., 26, 99-106, 1992.

Chipperfield, M. P. and Pyle, J. A.: Model sensitivity studies of Arctic ozone depletion, J. Geophys. Res., 103, 28 389-28 403, 1998.

Danckwerts, P. V.: Gas-Liquid Reactions, McGraw-Hill, New York, 276, 1970.

Danilin, M. Y. and McConnell, J. C.: Stratospheric effects of bromine activation on/in sulfate aerosol, J. Geophys. Res., 100, 11 237-11 243, 1995.

Fan, S.-M. and Jacob, D. J.: Surface ozone depletion in Arctic spring sustained by bromine reactions on aerosols, Nature, 359, 522-524, 1992.

Finlayson-Pitts, B. J. and Pitts Jr., J. N.: Chemistry of the Upper and Lower Atmosphere, Academic Press, San Diego, 969, 2000.

Foster, K. L., Plastridge, R. A., Bottenheim, J. W., Shepson, P. B., Finlayson-Pitts, B. J., and Spicer, C. W.: The role of $\mathrm{Br}_{2}$ and $\mathrm{BrCl}$ in surface ozone destruction at polar sunrise, Science, 291, 471-474, 2001.
Hanson, D. R. and Ravishankara, A. R.: Uptake of $\mathrm{HCl}$ and $\mathrm{HOCl}$ onto sulfuric acid: Solubilities, diffusivities, and reaction, J. Phys. Chem., 97, 12 309-12 319, 1993.

Hanson, D. R.: Reactivity of $\mathrm{BrONO}_{2}$ and $\mathrm{HOBr}$ on sulfuric acid solutions at low temperatures, J. Geophys. Res., 108, 4239, doi:10.1029/2002JD002519, 2003.

Hileman, B.: Methyl bromide phaseout stymied, Chem. \& Eng. News, 83, 30-31, 2005.

Huthwelker, T., Peter, T., Luo, B. P., Clegg, S. L., Carslaw, K. S., and Brimblecombe, P.: Solubility of $\mathrm{HOCl}$ in water and aqueous $\mathrm{H}_{2} \mathrm{SO}_{4}$ to stratospheric temperatures, J. Atmos. Chem., 21, 8195, 1995.

Iraci, L. T., Essin, A. M., and Golden, D. M.: Solubility of methanol in low-temperature aqueous sulfuric acid and implications for atmospheric particle composition, J. Phys. Chem. A, 106, 40544060, 2002.

Johnson, D. G., Traub, W. A., Chance, K. V., and Jucks, K. W.: Detection of $\mathrm{HBr}$ and upper limit for $\mathrm{HOBr}$ : Bromine partitioning in the stratosphere, Geophys. Res. Lett., 22, 1373-1376, 1995.

Klassen, J. K., Hu, Z., and Williams, L. R.: Diffusion coefficients for $\mathrm{HCl}$ and $\mathrm{HBr}$ in $30 \mathrm{wt} \%$ to $72 \mathrm{wt} \%$ sulfuric acid at temperatures between 220 and 300 K, J. Geophys. Res., 103, $16197-$ $16202,1998$.

Klassen, J. K., Lynton, J., Golden, D. M., and Williams, L. R.: Solubility of acetone in low-temperature (210-240 K) sulfuric acid solutions, J. Geophys. Res., 104, 26 355-26361, 1999.

Lary, D. J., Chipperfield, M. P., Toumi, R., and Lenton, T.: Heterogeneous atmospheric bromine chemistry, J. Geophys. Res., 101, 1489-1504, 1996.

Martinez, M., Arnold, T., and Perner, D.: The role of bromine and chlorine chemistry for Arctic ozone depletion events in $\mathrm{Ny}$ Alesund and comparison with model calculations, Ann. Geophys., 17, 941-956, 1999,

SRef-ID: 1432-0576/ag/1999-17-941.

Matveev, V., Peleg, M., Rosen, D., Tov-Alper, D. S., Hebestreit, K., Stutz, J., Platt, U., Blake, D., and Luria, M.: Bromine oxideozone interaction over the Dead Sea, J. Geophys. Res., 106, 10375-10388, 2001.

Michelsen, H. A., Spivakovsky, C. M., and Wofsy, S. C.: Aerosolmediated partitioning of stratospheric $\mathrm{Cl}_{\mathrm{y}}$ and $\mathrm{NO}_{\mathrm{y}}$ at temperatures above 200 K, Geophys. Res. Lett., 26, 299-302, 1999.

Montzka, S. A., Butler, J. H., Hall, B. D., Mondeel, D. J., and Elkins, J. W.: A decline in tropospheric organic bromine, Geophys. Res. Lett., 30, 1826, doi:10.1029/2003GL017745, 2003.

Murphy, D. M. and Thomson, D. S.: Halogen ions and $\mathrm{NO}^{+}$in the mass spectra of aerosols in the upper troposphere and lower stratosphere, Geophys. Res. Lett., 27, 3217-3220, 2000.

Rosenlof, K. H., Oltmans, S. J., Kley, D., et al.: Stratospheric water vapor increases over the past half-century, Geophys. Res. Lett., 28, 1195-1198, 2001.

Sander, R.: Compilation of Henry's Law Constants for Inorganic and Organic Species of Potential Importance in Environmental Chemistry (version 3), http://www.mpch-mainz.mpg.de/ $\sim_{\text {sander/res/henry.html, } 1999 .}$

Sander, S. P., Friedl, R. R., Golden, D. M., et al.: Chemical Kinetics and Photochemical Data for Use in Atmospheric Studies, Eval. 14 Ed.; Jet Propulsion Laboratory, Pasadena, CA, 2003.

Sinnhuber, B.-M., Arlander, D. W., Bovensmann, H., et al.: Comparison of measurements and model calculations of strato- 
spheric bromine monoxide, J. Geophys. Res., 107, 4398, doi:10.1029/2001JD000940, 2002.

Steele, H. M. and Hamill, P.: Effects of temperature and humidity on the growth and optical properties of sulphuric acid-water droplets in the stratosphere, J. Aerosol Sci., 12, 517-528, 1981.

Wang, T. X., Kelley, M. D., Cooper, J. N., Beckwith, R. C., and Margerum, D. W.: Equilibrium, kinetic, and UV-spectral characteristics of aqueous bromine chloride, bromine, and chlorine species, Inorg. Chem., 33, 5872-5878, 1994.

Waschewsky, G. C. G. and Abbatt, J. P. D.: HOBr in sulfuric acid solutions: Solubility and reaction with $\mathrm{HCl}$ as a function of temperature and concentration, J. Phys. Chem. A, 103, 5312-5320, 1999.

Wexler, A. S. and Clegg, S. L.: Atmospheric aerosol models for systems including the ions $\mathrm{H}^{+}, \mathrm{NH}_{4}^{+}, \mathrm{Na}^{+}, \mathrm{SO}_{4}^{2-}$, $\mathrm{NO}_{3}^{-}, \mathrm{Cl}^{-}, \mathrm{Br}^{-}$, and $\mathrm{H}_{2} \mathrm{O}$, J. Geophys. Res., 107, 4207, doi:10.1029/2001JD000451, http://mae.ucdavis.edu/wexler/aim. html, 2002.

Williams, L. R. and Golden, D. M.: Solubility of $\mathrm{HCl}$ in sulfuric acid at stratospheric temperatures, Geophys. Res. Lett., 20, 2227-2230, 1993.
Williams, L. R., Golden, D. M., and Huestis, D. L.: Solubility of $\mathrm{HBr}$ in sulfuric acid at stratospheric temperatures, J. Geophys. Res., 100, 7329-7335, 1995.

Williams, L. R. and Long, F. S.: Viscosity of supercooled sulfuric acid solutions, J. Phys. Chem., 99, 3748-3751, 1995.

World Meteorological Organization: "Scientific Assessment of Ozone Depletion: 2002”, Global Ozone Research and Monitoring Project - Report No. 47, 2003.

Worsnop, D. R., Zahniser, M. S., Kolb, C. E., Gardner, J. A., Watson, L. R., Van Doren, J. M., Jayne, J. T., and Davidovits, P.: Temperature dependence of mass accommodation of $\mathrm{SO}_{2}$ and $\mathrm{H}_{2} \mathrm{O}_{2}$ on aqueous surfaces, J. Phys. Chem., 93, 1159-1172, 1989.

Zhang, R., Wooldridge, P. J., Abbatt, J. P. D., and Molina, M. J.: Physical chemistry of the $\mathrm{H}_{2} \mathrm{SO}_{4} / \mathrm{H}_{2} \mathrm{O}$ binary system at low temperatures: Stratospheric implications, J. Phys. Chem., 97, 73517358, 1993. 